DOI: $10.1515 / \mathrm{rpp}-2016-0025$

Postgraduate Student, YULIIA SUKHOMUDRENKO

Bohdan Khmelnytskyi Cherkasy National University, Ukraine

Address: 81 Shevchenko Blvd, Cherkasy, 18031, Ukraine

E-mail: yulia-kisa2@rambler.ru

\title{
IMPLEMENTATION OF MULTIMEDIA TECHNOLOGIES INTO THE EDUCATIONAL PROCESS IN DEVELOPED COUNTRIES
}

\begin{abstract}
In the context of information technology development of a society requirements to professional training of teachers and forming of their competencies are increasing. The need for provision of media education consistent with challenges of an information society, organization of pedagogues' in the field of media education training, based on media needs of the youth, development of innovative approaches and implementation of effective media education models into all the segments of education has been emphasized. Informatization is becoming a leading trend in education modernization that causes the need for advancing a level of teachers' training, as the latter should possess information technologies. Thus, special attention should be paid to implementation of new learning forms that presuppose the use of computer resources. Ukraine requires an intensive informatization of the education system. Quite urgent for Ukrainian education system is the implementation of new multimedia technologies into the educational process of primary, secondary, high schools and higher education institutions. So, teachers' training for the use of multimedia technologies is a topical task of teacher education. Based on the analysis of native and foreign works dedicated to the problem of use of computer technologies it has been concluded that in different countries the potential of multimedia technologies has been used since the 1970s and 80s. The experiment on the implementation of multimedia technologies into the educational process was conducted; computer programs, textbooks and methodical recommendations for teachers were developed; main directions of school informatization were outlined; the staff problem was being solved; people's adaptation to life in an information society was launched. In the 1990s education projects were realized, the need for education informatization was reflected on subject programs; general and specific trends in the development of education informatization in different countries were emphasized.
\end{abstract}

Key words: information and communication technologies, multimedia technologies, computer technologies, education informatization, the Internet.

\section{INTRODUCTION}

The $21^{\text {st }}$ century is presenting a range of new demands on education, namely, adaptation to application of new learning technologies based on use of modern computer resources and implementation of scientific and information technologies.

As a rule, modern pedagogically effective electronic means of learning are developed to maintain new pedagogical technologies. Teachers should both possess information and communication technologies (ICT) and apply new pedagogical technologies, modern methods and organizational forms of learning to use such electronic resources effectively. Thus, an abundance of large-scale projects on teaching pedagogues to apply ICT to the educational process have been launched in Belgium, Germany, Denmark, Turkey, Russia, Ukraine (Смірнова-Трибульська, 2001). However, not all teachers who participated in such projects started using these technologies. Methodical guides on electronic resources 
application were created to contribute to teachers' creativity; certain countries (Singapore, Chile, the USA) launched grant competitions to support group projects associated with ICT implementation; teachers engaged in providing implementation of multimedia technologies at schools were offered additional payment (Беспалько, 1966).

\section{THE AIM OF THE STUDY}

The aim of the study consists in justifying the need for innovative multimedia technologies implementation into practice of higher education to enhance the efficiency of the educational process.

\section{THEORETICAL FRAMEWORK AND RESEARCH METHODS}

Theoretical framework of our study comprises normative and legal base of the issues on the implementation of innovative technologies into education system of Ukraine, namely, the 1722-r Decree of the Cabinet of Ministers of Ukraine dated 27 August, 2010 on ratification of "Conception of State Target Program of "Sto Vidsotkiv" Information and Communication Technologies Implementation into the Educational Process in Comprehensive Schools in $2015 "$ "

To fullfill the aim of the study we have used such methods as analysis, synthesis, generalization and systematization of Ukrainian experience in the context of the problem raised, comparative and analytical.

\section{RESULTS}

The transfer to scientific and information technologies is creating new opportunities and outlining demands and objectives of conscious and effective functioning in the context of global information society, thereby enabling education and science to take it to the next level.

Researches dedicated to the problem of higher education computerization are being carried out in many countries of the world. The use of technical means of learning and computer technologies has been a topical issue for educators from the leading countries already for a century now.

Thus, scholars from all over the world, namely, Yu Haiashi, V. Hanenko, Ya. Hrechko, A. Kaplun, H. Kiedrovych, I. Kovchyna, K. Moritz, L. Yurchuk, have studied the abovementioned problem.

For the first time the idea of "information society" was justified in the 1960s by researchers from Tokyo Technological Institute under the direction of Prof. Yu Hayashi (Шевчук, Голобуцький, 2001).

In Sweden the education informatization began in the 1970s. National Council for Higher Education together with universities and colleges started implementing a range of research projects on the use of computer means in learning. At the same time learning of computer programming within mathematical and some technical subjects was introduced in several secondary schools. The projects were completed at the beginning of the 1980 s and the experience in their organization enabled outlining further strategies for implementing computer learning in schools. Based on the results of the experiment it was decided to introduce new syllabi including computer literacy at universities (Каптелинин, 1992).

Although informatization of French education was launched in 1970, it advanced only in the 1980s. Main directions suggested included the use of computers as a means of learning; programming learning support; study of the object. In 1983 the Ministry of National Education outlined main trends in primary school informatization - the stage of "acquainting with information science": humanitarian and social (influence of computers on person and society); technological stage presupposing practical use of ICT as a means of direction; logical stage including all aspects of programming (Суховірський, 2005). 
In 1978 a group of Bulgarian scholars, teachers and programmers developed a computerized model of education reform grounded on the integration of certain subjects with the use of information technologies. The experiment lasted for twelve years (1979-1991) in twenty-nine Bulgarian schools. The set of learning material developed for these scools included textbooks, teacher's guides and standardized computer centers elaborated for each subject. The results showed that the pupils who participated in the experiment and the pupils of ordinary schools obtained similar knowledge, though participants of the experiment became more interested in the topic and had less physical and mental pressure. The obtained experience facilitated the implementation of education projects at school and university levels, namely, "Geomland", "Logo" and "Comenius Logo". In modern education Bulgarian scholars focus on the forming of future teachers' computer literacy and abilities to use multimedia technologies (Сендова, 1997).

Since 1996 the education program "Science in Technological Society" (MABAT) aimed at facilitating young generation's adaption to life in a modern information society has been implemented in Israeli schools. This program provides for mastering different subjects that include modern information technologies (laboratories equipped with computers, databases with new learning programs, multimedia equipment and Logo-Lego). Advanced teacher training courses were introduced to enhance the efficiency of the project. It should be mentioned that more than 35 thousand teachers participated in them. New learning and methodical materials created with the help of computer resources were published. Multimedia equipment in schools was systematically renewed and modernized, trainings and seminars for teachers and school administrators were held. All these measures enabled advancement of education level, development of pupils' analytical thinking and abilities to find necessary information (Проект программы начального образования, 1996).

Theoretical analysis of the issue on future teachers' multimedia learning testifies its insufficient development, especially in the context of scientific study and implementation of foreign experience.

Polish experience is of our great interest as it is an example for Ukraine in applying multimedia technologies to education. It was studied by V. Hanenko, Ya. Hrechko, A. Kaplun, I. Kovchyna, K. Moritz, L. Yurchuk and many others (Гавриш, 2005). The problem of future teachers' training with the use of multimedia technologies in higher education institutions of Ukraine in terms of foreign experience, Polish one, in particular, requires special attention.

Polish scholars have been actively searching for optimal ways to improve teacher advancement training in higher education institutions. First of all, they emphasize on improvement of teacher education via forming professional competency of future teachers and prefer realization of the most effective conceptions and models of teachers' professional training under modern conditions. Ukraine needs intensive development of education informatization process. Urgent for national education is implementation of new multimedia technologies into the educational process of secondary and higher education as they are obligatory for the scientific and technical progress. As we can see, teachers' training with the use of multimedia technologies is rather topical. It should be noted that Poland takes the lead over Ukraine regarding many indicators for successful solution to this problem. Professional training of a future teacher is based on philosophy of education, theory of pedagogical systems, theory of personality and his/her activities, information theory, didactic theories of scientific knowledge presentation. Main statement in the conception of future teachers' training is a properly organized creative information students' activity with the use of 
multimedia technologies oriented towards creation of professional and personally significant products and being a basis for teachers' professional enhancement (Андрієвська, 2009).

In Poland education informatization consists of two components: teaching specific field of information science and use of information technologies, computers and pedagogical programming means (syllabi) on lessons from other disciplines, in particular (Смірнова-Трибульська, 2001).

G. Kiedrowicz suggests using multimedia technologies as one of the most effective means of education informatization (Kiedrowicz, 1997).

The autonomy of Polish higher education institutions has caused a range of difficulties in coordinating information learning. The attempt was made to improve the situation, namely, in 2003 a program was established. It was divided into three blocks: information block - obtaining qualification in the field of information resources and technologies use ( 75 hours); methodical block - obtaining skills in using modern resources and tools of multimedia technologies while teaching (45 hours); additional block extending person's education via information knowledge (30 hours) (Kiedrowicz, 2007).

In our opinion, such approach can optimize youth adaptation to life in an information society.

Polish Informatization Strategy for 2004-2006 provided for economic development within three braches: A - Internet access; B - content and available services on the Internet; $\mathrm{C}$ - abilities to use teleinformation (Piecuch, 2006).

In Ukraine development of information technologies in learning started at the beginning of the 1960s (primarily in schools). The most common are automatized learning systems. Computable facilities of that time were expensive and imperfect that rather limited functions of such systems. Mainly they were reference and testing systems based on the principles of programming learning (Биков, 2010).

Education informatization started in the 1970-1980s when information technologies were being actively implemented into education administration.

Significant meaning for informatization in Ukraine is the 1722-r Decree of the Cabinet of Ministers of Ukraine dated 27 August, 2010 on ratification of "Conception of State Target Program of "Sto Vidsotkiv" Information and Communication Technologies Implementation into the Educational Process in Comprehensive Schools in 2015" («Сто відсотків»). This program is aimed at improving the quality of education and forming information society and competitive economy. In was indicated that at the present stage implementation of information and communication technologies into education is a national priority. Under the conditions of forming and developing highly technological society there is a need for complete implementation of ICT into the educational process of comprehensive schools (“Сто відсотків").

Active use of modern ICT in the educational process proved the occurrence of similar problems, such as lack of specialists, able to teach such courses in schools. On account of the mentioned above we can conclude that there is a need for professional training of primary school teachers able to effectively use new multimedia technologies (Суховірський, 2005).

In different countries education informatization has its own specifics caused by peculiarities of resources, culture, education, traditions, etc.

So, education informatization started in the second half of the 19th century in different countries. This process presupposed establishment and realization of education projects, programs; planning of ways to prepare young generation to life in an information 
society; equipping laboratories with computers, syllabi, methodical materials, multimedia devices. In addition, advanced training courses aimed at forming teachers' computer literacy were organized and trainings were held.

Based on the analysis of psychological and pedagogical literature we can conclude that education informatization in different countries, preparation of pupils and students to life in an information society are carried out at the state level.

\section{CONCLUSIONS}

Based on the analysis of native and foreign works dedicated to the problem of use of computer technologies we can conclude that in different countries the potential of multimedia technologies has been used for education modernization since the1970-1980s. Multimedia technologies are being implemented into the educational process; computer programs, textbooks and methodical recommendations for teachers are being developed; main trends in school informatization are being outlined; staff problems are being resolved; people's preparation for life in an information society was launched. In the 1990s information projects were realized; the need for education informatization was reflected on the syllabi of subjects; common and specific trends in development of education informatization in different countries were emphasized.

\section{REFERENCES}

1. Kiedrowicz, G. (2007). Kwalifikacje informatyczne współczesnego nauczyciela [Information Qualification of Modern Teacher]. Ewolucja kwalifikacji nauczycieli w kontekście przemian edukacyjnych [Evolution of Teacher's Qualification in the Context of Changes in Education], pp. 237-244 (in Polish).

2. Kiedrowicz, G. (1997). Multimedialne wspomaganie nauczania przedmiotów ogólnokształcacych [Multimedia Support for Teaching at School]. Radom : Politechnika Radomska, 42 p. (in Polish).

3. Piecuch, A. Z. (2006). Teorii i praktyki uczenia się i nauczania informatyki [Theory and Practice of Teaching and Learning Information Science]. Dydaktyka informatyki: problemy uczenia się $i$ nauczania informatyki $i$ technologii informacyjnych [Information Science Didactics: Problems of Teaching and Learning Information Science and Information Technology], pp. 56-67 (in Polish).

4. Андрієвська, В. М. (2009). Проектування дидактичних ситуачій у навчанні молодших школярів з використанням комп'ютера [Designing Didactic Situations in Teaching Young Learners with the Use of Computer]. Abstract of Thesis for PhD. Харків : Харківський національний університет ім. Г. Сковороди, 20 р. (in Ukrainian).

5. Беспалько, В. П. (1966). Методические рекомендации по программированному обучению [Methodical Recommendations on Programming Learning]. М. : Республиканский учебно-методический кабинет, 233 р. (in Russian).

6. Биков, В.Ю.(2010). Сучасні завдання інформатизації освіти [Modern Objectives of Education Informatization]. Інформаційні технології $і$ засоби навчання: електронне наукове фахове видання [Information Technologies and Means of Learning : Electronic Scientific Professional Journal], No 1 (15). Retrieved 20.05.2016 from : http://www.ime.edu-ua.net/em15/emg.html.

7. Гавриш, I. В. (2005). Закономірності та принципи процесу формування готовності майбутніх учителів до інноваційної професійної діяльності [Patterns and Principles of Forming Future Teachers' Readiness to Innovative Professional Activity]. 
Дійсність та перспективи розвитку сучасної освіти України [Reality and Prespectives of modern Education Development in Ukraine], pp. 61-74 (in Ukrainian).

8. Кабінет Міністрів України. (2010). Про схвалення Концепиії Державної иільової програми впровадження у навчально-виховний процес загальноосвітніх навчальних закладів інформаційно-комунікаиійних технологій «Сто відсотків»: Розпорядження, від 27 сериня 2010 р. № 1722-p. [On ratification of “Conception of State Target Program of "Sto Vidsotkiv" Information and Communication Technologies Implementation into the Educational Process in Comprehensive Schools in 2015": the 1722-r Decree dated 27 August, 2010]. Retrieved 20.05.2016 from : http://zakon.rada.gov.ua/cgi-bin/laws/main.cgi? nreg $=1722-2010-\%$ F0.

9. Каптелинин, В. Н. (1992). Компьютеры в обучении: шведский путь [Computers in Learning: Swiss Experience]. Информатика и образование [Infirmation Science and Education], No 1, pp. 112-117 (in Russian).

10. Проект программы начального образования [Draft of the Primary Education Curriculum]. (1996). Информатика и образование [Information Science and Education], No 2, pp. 121-122 (in Russian).

11. Сендова, Е. (1997). Унификационные компьютерные среды: болгарская модель образования [Unificated Computer Environments]. Информатика и образование [Information Science and Education], No 8, pp. 109-113 (in Russian).

12. Смірнова-Трибульська, С. М. (2001). Структура та зміст інформаційної освіти у Польщі [Structure and Content of Information Education in Poland]. Комn'ютер у школі та сім' $̈$ [Computer at School and Home], No 6, pp. 47-50 (in Ukrainian).

13. Суховірський, О.В. (2005). Підготовка майбутнього вчителя початкової школи до використання інформаційних технологій [Future Primary School Teachers' Prepararion to Use of Information Technologies]. Thesis for $\mathrm{PhD}$. - K. : Інститут педагогіки АПН України, 303 p. (in Ukrainian).

14. Шевчук, О. Б., Голобуцький, О. П. (2001). E-Ukraine. Інформаційне суспільство: бути чи не бути [E-Ukraine. Information society: to Be or not to Be]. К. : ЗАТ “Атлант UMS”, 104 p. (in Ukrainian). 